\title{
PENELITIAN
}

\section{Optimalisasi Pelayanan Nasabah Bank dengan Teori Antrian}

\author{
Oleh : Ir. Chalrul Saleh
}

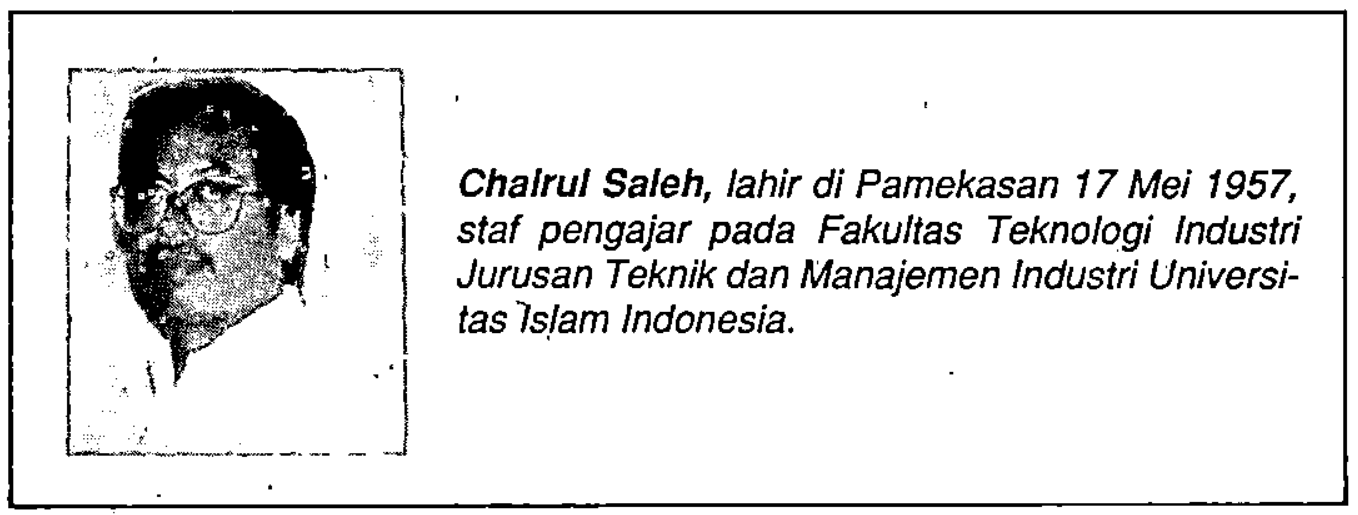

\section{Pengantar}

Usaha perbankan menupakan suatu usaha yang besar dan mempunyai arti yang penting baik bagi pemerintah, industri, masyarakat maupun kegiatan perdagangan. Ruang lingkup operasinya meliputi Nasional maupun Internasional.

Semakin banyak bermunculan bank sejak adanya deregulasi 27 Oktober 1988 sehingga persaingan antar bank semakin ketat termasuk persaingan pelayanan terhadap nasabah. Pelayanan terhadap nasabah tentu saja harus mendapatkan perhatian yang besar, karena dengan banyaknya nasabah yang datang tentu saja akan membawa keuntungan yang besar terhadap bank tersebut.

Namun demikian, faktor efisiensi pelayanan terhadap nasabah ini harus juga diperhitungkan sedemikian rupa sehingga baik bank maupun nasabah tidak dirugikan. Peningkatan pelayanan terhadap nasabah ini dapat dianalisa dengan berbagai macam cara diantaranya dengan teóri antrian, sehingga tingkat optimalisasi dari pelayanan dan yang dilayani dapat diketahui dengan baik.

Nasabah yang datang bukan saja untuk kepentingan kredit saja dapat juga untuk menabung atau melakukan transfer pengiriman uang. Lonjakan nasabah baik secara kuantitas maupun kualitas dapat kita lihat baik pada bank pemerintah maupun bank swasta, sehingga dapat kita lihat muncul adanya antrian nasabah untuk diláyani. Tentu saja hal ini akan membawa pengaruh terhadap pelayanan yang hạrus dilakukan oleh bank kepada para nasabah, sehingga optimalisasi pelayanan terhadap nasabah diperlukan untuk mempertahankan dan menarik bertambahnya nasabah pada masa yang akan datang.

\section{Persoalan yang dihadapi}

Suatu antrian ialah suatu garis tunggu dari nasabah yang memerlukan layanan 
dari satu atau lebih pelayan (fasilitas layanan). Kejadian antrian ini merupakan suatu fenomena biasa yang terjadi apabila kebutuhan akan suatu pelayanan melebihi kapasitas yang tersedia untuk menyelenggarakan pelayanan tersebut.

Garis tunggu ini sering disebut orang dengan antrian, sedangkan studi matematis dari kejadian atau gejala garis tunggu ini disebut teori antrian (Winston; 1987).

Keputusan untuk menentukan jumlah kapasitas pelayanan yang optimal selalu menjadi persoalan yang serius bagi perusahaan-perusahaan industri ataupuri yang lainnya. Bagaimanapun juga sering tidak mungkin untuk dapat meramalkan secara pasti kapan nasabah akan datang memerlukan pelayanan dan atau berapa lama waktu yang dibutuhkan untuk melayani nasabah.

Disamping' itu juga perlu diperhatikan adanya keseimbangan ekonomis antara ongkos pelayanan dan ongkos menunggu dalam antrian dari masing-masing pihak. Penyediaan stasiun pelayanan dalam jumlah yang berlebihan akan merugikan perusahaan, Dilain pihak dengan tidak menyediakan stasiun pelayanan dalam jumlah yang cukup akan menyebabkan keluamya ongkos yang lain. misalnya ongkos kehilangan langganan, ongkos sosial dan scbagainya akibat terlalu lamanya waktu menunggu dalam antrian oleh nasabah.

- Walaupun demikian keputusan yang didasarkan pertimbangan ongkos ini sering tidak praktis dalam hal posisinya berada di luar organisasi perusahaan. Untuk perusahaan yang memberikan pelayanan berdasarkan laba yang diperoleh, menurut anggapan pengambil keputusan, ongkos menunggu sangat berhubungan dengan kehilangan keuntungan, karena langganan (nasabah) akan berpindah ketempat lain sehingga transaksi menjadi batal.

Ongkos ini bisa segera kelihatan bila nasabah yang sedang berada dalam antrian memutuskan untuk meninggalkan antrian. Sedangkan kerugian untuk jangka panjang. nasabah akan merasa jemu berhubungan kembali dengan perusahaan tersebut. Untuk perusahaan yang memberikan pelayanan non profit, ongkos menunggu biasanya berhubungan dengan ongkos-ongkos sosial.

Berdasarkan hal tersebut diatas maka perlu diketahui karakteristik sistem antrian sehingga dengan demikian penentuan jumlah fasilitas pelayanan yang optimal dapat dihitung.

\section{Maksud studi}

Studi bertujuan :

(1) Sejauh mana aplikasi teori antrian dapat dilaksanakan dalam menganalisa pelayan nasabah bank.

(2) Mencari metode lain jika ada penyimpangan terhadapkarakteristik sistẹm antrian.

\section{Kerangka Teoritik}

1. Komponen Dasar proses garis antrian. Komponen dasar dari proses garis antrian adalah kedatangan nasabah (arrival), pelayanan (servers), dan garis tunggu (queues) atau waiting line. Ketiga komponen dasar tersebut dapat digambarkan sebagai berikut :

1.1. Kedatangan (Arrival)

Setiap persoalan antrian tentu saja berhubungan dengan kedatangan dari

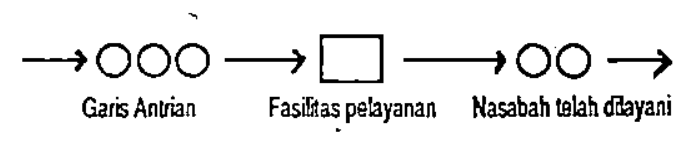

Gambar 1 
suatu item yang perlu dilayani seperti nasabah bank, peralatan atau mesinmesin dan lainnya. Elemen dari proses antrian selalu bertitik tolak pada proses masukan (input proses). Sedangkan input proses adalah sumber kedatangan yang biasanya merupakan bentuk proses random atau acak. Ukuran dari populasi kedatangan tak terbatas. Jumlah kedatangan perunit waktu pada umunnya dapat diestimasi dengan distribusi probabilitas mengikuti probabilitas Poison. Sedangkan distribusi dari waktu selisih antara 2 kedatangan nasabah adalah mengikuti probabilitas distribusi eksponensial.

$$
\begin{aligned}
P(x)= & \frac{\mathrm{e}^{-\lambda} \lambda^{\mathrm{x}}}{\mathrm{x} !} \text { untuk } \mathrm{x}=1,2,3, \ldots \\
\mathrm{P}(\mathrm{x})= & \begin{array}{l}
\text { probalibilitas } \\
\text { kedatangan nasabah }
\end{array} \\
\mathrm{x} & =\begin{array}{l}
\text { jumlah kedatangan per unit } \\
\text { waktu }
\end{array} \\
\lambda & =\text { rata-ratajumlah kedatangan } \\
\mathrm{e} & =\text { bilangan alam (2.7183) }
\end{aligned}
$$

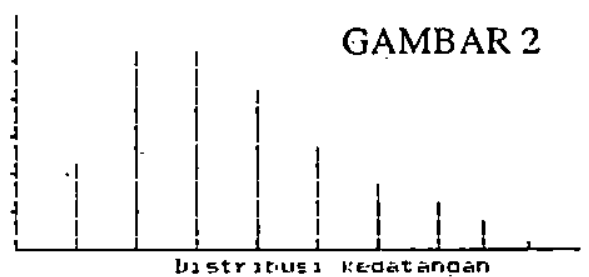

\subsection{Pelayanan (server)}

Yang dimaksud dengan pelayanan adalah fasilitas untuk melayani yang bentuknya bisa orang atau mesin. Mekanisme pelayanan dalam antrian dapat terjadi satu atau lebih pelayanan. Sedangkan proses pelayanan ini selalu mengikuti proses random yang pada umumnya mengikuti probabilitas distribusi negatif ek'sponensial. Gambar 3 dibawah ini adalah contoh
Distribusi negatif eksponensial.

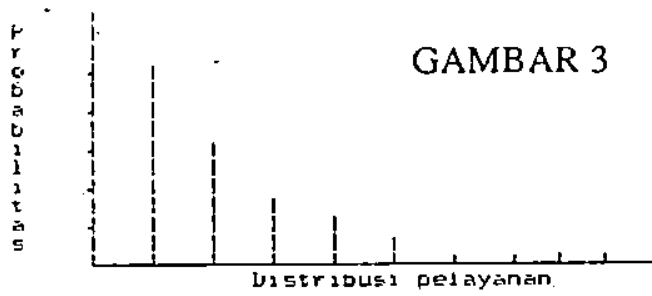

1.3. Antrian (Queuing)

Dalam analisa antrian tentu saja yang dianalisa antrian itu sendiri. Namun demikian hal yang utama adalah tergantung pada proseskedatangan dan pelayanan itu sendiri. Disamping itu bentukdari Disiplin Antrian (Queuing Discripline) mempengaruhi dalam penganalisaannya.

Disiplin pelayanan adalah kebijakan dalam mana para nasabah dari antrian untuk dilayani. Ada 4 bentuk disiplin pelayanan yang biasa digunakan dalam praktek, yaitu:

1. First Come First Serverd (FCFS) atau First In First Out (FIFO). Artinya nasabah yang datang lebih dahulu dilayani terlebih dahulu, misalnya pembelian tiket bioskop.

2. Last Come First Serverd (LCFS) atau Last In First Out (LIFO) Artinya yang datang terakhir lebih dahulu dilayani, misalnya antrian dalam elevator/lift untuk lantai yang sama.

3. Service In Random Order (SIRO) Artinya pelayanan didasarkan pada peluang secara random, dalam hal ini tidak dipersoalkan yang mana datang terdahulu.

4. Priority Service (PS)

Artinya pelayanan diberikan berdasarkan prioritas lebih tinggi. Kejadian ini sering dijumpai pada antrian pasien di rumah sakit. 
2. Konfigurasi Dasar Sistem Antrian Struktur dasar proses antrian dibagi dalam 4 kategori. Pembagian ini didasarkan pada keadaan fasilitas pelayanan yang tersedia yaitu :
(A). Single Channel, Single Phase
(B). Multiple Channel, Single Phase
(C). Single Channel, Multiple Phase
(D). Multiple Channel, Multiple Phase

Gambar 4, dibawah ini dapat menerangkan dari ke 4 kategori tersebut.

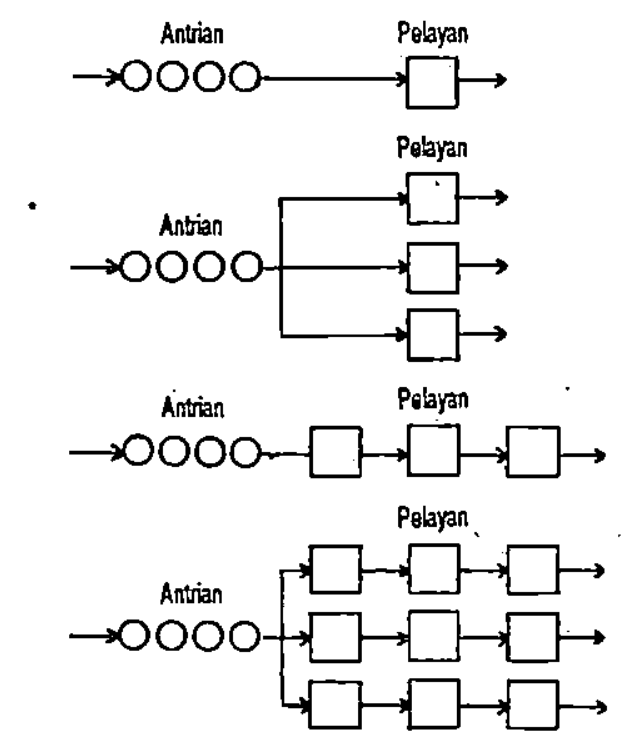

GAMBAR 4

Jumlah Channel dalam proses antrian adalah jumlah paralel pelayanan yang tersedia untuk melayani nasabah yang datang, sedangkan jumiah phase adalah jumlah urutan langkah pelayanan dari individu nasabah yang datang yang merupakan keharusan untuk dilakukan.

\section{Jenis Model Antrian}

Ada 4 macam model antrian yang biasa digunakan secara luas, keempat model tersebut adalah Simple System, MultiChannel, Constant Service dan Limited Population. Dari semua ini biasanya menggunakan 3 macam asumsi yaitu:

- Kedatangan nasabah mengikuti distribusi Poison

- Disiplin antrian adalah FIFO

- Mengikuti phase tunggal pelayanan (Single Service-Phase)

4. Rumus-rumus yang Dipakai Dalam Model Antrian

Rumus yang digunakan untuk setiap model tentu saja ada perbedannya hal ini disesuaikan dengan model antrian yang dihadapi. Dalam tulisan ini rumus yang disajikan tidak akan dijelaskan secara mendalam dari mana asalnya.

\subsection{Rumus Untuk Model Simple System}

$\lambda \quad=$ Rata-rata jumlah kedatangan nasabah per periode waktu

= Rata-rata jumlah nasabah yang dilayani per periode

= Jumlah rata-rata nasabah didalam sistem

$$
=\frac{\lambda}{\mu-\lambda}
$$

Ws ${ }^{-}=$Rata-rata waktu yang dikeluar kan nasabah dalam sistem (waktu menunggu + waktu pelayanan)

$$
=\frac{1}{\mu-\lambda}
$$

Lq = Rata-rata jumlah unit dalam antrian menunggu pelayanan 


$$
=\frac{\lambda^{2}}{\mu(\mu-\lambda)}
$$

$\mathrm{Wq}=$ Rata-rata waktu yangdikeluar kan oleh nasabah dalam antrian

$$
=\frac{\lambda}{\mu(\mu-\lambda)}
$$

$\rho=$ Faktor utilitas untuk sistem

$$
\therefore \frac{\lambda}{\mu}
$$

Po = Kemungkinanadanyakosong (0) nasabah dalam sistem

$$
=1-\frac{\lambda}{\mu}
$$

Pn>k = Probabilitas dari sejumlah $\mathrm{k}$ nasabah dalam sistem dimana $n$ adalah jụmlah nasabah dalam sistem

$$
=\left\{\frac{\lambda}{\mu}\right\}^{k+1}
$$

\subsection{Rumus Untuk Model Multi Channel System}

M = Jumlah Channel yang dibuka

$\lambda=$ Rata-rata jumlah kedatangan nasabah

$\mu \quad=$ Rata-rata jumlah nasabah yang dilayani pada setiap channel

Po = Probabilitas bahwa sejumlah kosong (0), nasabah dalam system

$$
=\frac{1}{\left[\sum_{n=0}^{+-1} \frac{1}{n !}\left(\frac{\lambda}{\mu}\right) \div \frac{1}{M !}\left(\frac{\lambda}{\mu}\right) \frac{M \mu}{M \mu-\lambda}\right]} \text { unluk } M \mu>k
$$

Ls = Jumlah rata-rata nasabah dalam sistem

$$
=\frac{\lambda \mu(\lambda / \mu)^{M}}{(M-1) !(M \mu-\lambda)^{2}} \text { Po }_{+}+\frac{\lambda}{\mu} \text {. }
$$

Ws =Rata-rata waktu . yang dikeluarkan nasabah dalam sistem antrian

$$
=\frac{M(\lambda / \mu)^{\mu}}{(M-1) !(M \mu-\lambda)^{2}} P_{0}+\frac{1}{\mu}=\frac{L s}{\lambda}
$$

$\mathrm{Lq}=\mathrm{Jumlah}$ rata-rata nasabah dalam antrian menunggu pelayanan

$$
=\mathrm{Ls}-\frac{\lambda}{\mu}
$$

Wq = Rata-rata waktu yang dikeluarkan seorang nasabah dalam antrian untuk dilayani

$$
=W s-\frac{1}{\mu}=\frac{\mathrm{Lq}}{\lambda}
$$

\subsection{Rumus Untuk Model Constant Service}

$\lambda=$ Rata-rata jumlah kedatangan nasabah per periode waktu

$=$ Rata-rata jumlah nasabah yang dilayani per periode waktu

Lq = Rata-rata jumlah unit dalam antrian menuggu pelayanan 


$$
\begin{aligned}
&= \frac{\lambda^{2}}{2 \mu(\mu-\lambda)} \\
& \text { Wq }= \text { Rata-rata waktu yang } \\
& \text { dikeluarkanolehnasabah dalam } \\
& \text { antrian }
\end{aligned}
$$

Rumusan yang lain mengikuti sama denganmodel' simple system pada 4.1

\subsection{Rumus Untuk Model Constant Service}

$\mathrm{X} \quad=$ Faktor pelayanan

$$
=\frac{T}{T+U}
$$

L = Jumlah rata-rata nasabah menunggu dalam antrian untuk dilayani

$=\mathrm{N}(1-\mathrm{F})$

W - = Rata-rata seorang nasabah menunggu pada antrian

$$
=\frac{L(T+\mathrm{U})}{\mathrm{N}-\mathrm{L}}=\frac{\mathrm{T}(1-\mathrm{F})}{\mathrm{XF}}
$$

J = Rata-rata jumlah nasabah yang tidak ada dalam antrian

$=\mathrm{NF}(1-\mathrm{X})$

$\mathrm{H}$ = Rata-rata jumlah nasabah yang telah dilayani

$=$ FNX

$N \quad=$ Jumlah nasabah yang potensial

$=\mathrm{J}+\mathrm{L}+\mathrm{H}$

D = Probabilitas nasabah harus menunggu dalam antrian

F $\quad=$ Faktor efisiensi

M = Jumlah Channel pelayanan

$\mathrm{T}=$ Rata-rata waktu pelayanan

$\mathrm{U} \quad=$ Rata-rata waktu antara nasabah yang memerlukan pelayanan

\section{Subjek Studi}

Subjek studi dilakukan di Bank Rakyat Indonesia cabang Cik Di Tiro Yogyakarta pada loket Transfer.

\section{Dana Studi}

Dana studi yang berbentuk dana penelitian diperoleh dari Universitas Islam Indonesia melalui Lembaga penelitian Universitas Islam Indonesia.

\section{Analisis Data}

Data yang telah dikumpulkan kemudian dianalisis untuk mengetahui optimalisasi sistem antrian diloket Transfer Bank Rakyat Indonesia Cabang Cik Di Tiro Yogyakarta. Adapun data-data yang dikumpulkan dan ditabulasikan untuk analisis ini adalah data waktu antara dua kedatangan berturutan dari násabah terhadap ketiga fasilitas pelayanan tersebut diatas dan data waktu proses (pelayanan)nya.

\section{- Data Waktu Kedatangan Nasabah}

Duta waktu kedatangan nasabah yang akan diambil adalah waktu antara dua 
kedatangan yang berturutan terjadi. Misalkan saat kedatangan nasabah pertama, kedua, ketiga dan seterusnya adalah $t 1, t 2$, t3, ...tn; maka waktu kedatangan yang digunakan sebagai data adalah $\mathrm{X} 1, \mathrm{X} 2, \mathrm{X} 3$, ...Xn-1; dengan $\mathrm{Xn}-1=\mathrm{Xn}-\mathrm{Xn}-1$ dengan $\mathrm{n}$ $>2$.

Pengambilan data dilakukan pada periode-periode sibuk dari sistem yang diamati. Yaitu antara pukul, 8.15 sampai dengan pukul 12.00 dimana puncak permintaan pelayanan terjadi pada waktuwaktu tersebut. Agar data yang diperoleh secara benar, maka pengamatan dilakukan lebih dari 3 minggu.

\section{- Data Waktu Pelayanan Nasabah}

Pengamatan lamanya waktu pelayanan terhadap nasabah yang dalam hal ini identik dengan lamanya nasabah harus menunggu, dilakukan dengan menggunakanstop-watch, dengan ketelitian pengamatan adalah sampai dengan detik, artinya kelebihan waktu, kurang dari setengah detik akan diabaikan, sedangkan kelebihan waktu lebih dari setengah detik akan dibulatkan keatas. Datalamanya waktu pelayanan ini diambil saat tanda terima transfer diserahkan ke loket untuk mendapatkan pelayanan sampai nasabah menerimakembali berkas Transfer tersebut yang merupakan sebagai akhir dari proses pelayanan.

\section{- Pengolahan Data}

Dari data waktu kedatangan dan waktu pelayanan nasabah maka dibuātlah data baru yaitu data waktu antara dua kedatangan berturutan sedangḳan data lamanya pelayanan tidak mengalami perubahan bentuk. Analisis dari data yang diperoleh meliputi beberapa bagian, yaitu : a. Pengujian bentuk distribusi data yang meliputi:

1). Analisis pola kedatangan nasabah

2).Proses pelayanan kepada nasabah

b. Kecepatan kedatangan rata-rata nasabah

c. Kecepatan pelayanan rata-rata kepada 'nasabah

d. Analisis sistem antriandengankomputer

e. Analisis jumlah loket yang optimal berdasarkan hasil analisis sistem antrian.

\section{Penyajian Bentuk Distribusi Data}

Data hasil pengamatan waktu antara dua kedatangan berturut-turut dan data waktu pelayanan, tersusun suatu bentuk distribusi frekuensi berdasarkan interval waktu yang telah dihitung melalui ketentuan rumus, dan hasilnya dapat dilihat pada Tabel $1 \mathrm{~s} / \mathrm{d} 6$ dibawah ini.

A. Perhitungan Panjang Interval dilakukan sebagai berikut:

Sebaran $R=$ Nilai Data Tertinggi - Nilai Data Terendah.

$R=30,25-0=30,25$.

Jumlah kelas interval optimal

$\mathrm{C}=1+3,3 \log 296$

$=1+8,15=9,15$ dibulatkan 9

Panjang interval $\mathrm{R} / \mathrm{C}=30,25 / 9=3,33$

***. Untuk Perhitungan distribusi Frekuensi data waktu Pelayanandilakukan pula seperti cara diatas.

B. Analisa Pola waktu $2 \cdot$ Kedatangan nàsabah berurutan.

Analisa ini dilakukan untuk mengetahui pola waktu selisih 2 kedatangan nasabah. Tabel 1. dibawah ini adalah kelas interval waktu yang digunakan untuk mengetahui frekuensi waktu dari 2 kedatangan nasabah. 
Untuk perhitungan selanjutnya dilakukan perhitungan harga-harga rata populasi standar deviasi dan variansinya.

Harga rata-rata popúlasi, $t$ :

$$
\begin{aligned}
& \bar{t}=\frac{\sum_{i} f i \cdot t i}{\sum_{1} f i} \\
& \bar{t} \quad=2.133 \text { menit }
\end{aligned}
$$

Deviasi standar, $S=\frac{1}{(n-1)} \sqrt{2103,817}=0.155$ Dari perhitungan rata-rata populasi waktu antara 2 kedatangan nasabah diatas selanjutnya dapat dihitung kecepatan nasabah datang ke tempat pelayanan per satuan waktu $(\lambda)$.

$$
\lambda \doteq \frac{1}{\cdot \mathrm{t}}=0.4688
$$

Tábel 1

DISTRIBUSI FREKUENSI DATA WAKTU

ANTARA DUA KEDATANGAN NASABAH

BERTURUTAN

\begin{tabular}{|c|c|c|c|}
\hline$t i$ & $f i$ & $f i \cdot t i$ & $i i(t i-\bar{t})^{2}$ \\
\hline \multirow[t]{2}{*}{$\begin{array}{l}1,02 \\
4,652 \\
0,397 \\
10,350 \\
15,150 \\
0 \\
0 \\
0 \\
0 \\
30,25\end{array}$} & $\begin{array}{r}243 \\
30 \\
10 \\
3 \\
1 \\
0 \\
0 \\
0 \\
0 \\
1\end{array}$ & $\begin{array}{c}242,4 \\
178,296 \\
84,40 \\
30,93 \\
15,15 \\
0 \\
0 \\
0 \\
0 \\
30,25\end{array}$ & $\begin{array}{c}301,020 \\
248,842 \\
392,376 \\
201,572 \\
169 ; 442 \\
0 \\
0 \\
0 \\
0 \\
790,565\end{array}$ \\
\hline & 296 & 631,486 & 2103,817 \\
\hline
\end{tabular}

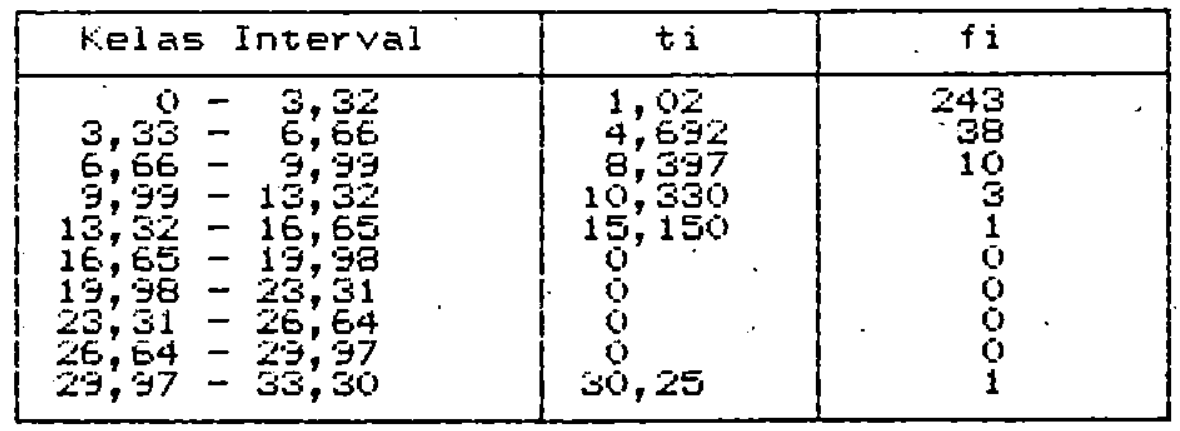

Tabel 2

Variansi, $\mathrm{S}^{2}=\frac{1}{(n-1)} \sum f(n i-\mathrm{t})^{2}$ $=7,1315$
Test statistik untuk mengetahui kesesuaian dari bentuk distribusi waktu antara 2 kedatangan yang diketahui dari gambar 5 . 
sesuai dengan bentuk distribusi Hasil perhitungan diperoleh

Eksponensial dilakukan sebagai berikut :

a. Dihitung Probabilitas dengan rumus :

$$
\operatorname{Pi}(t)=\int_{t l}^{t 2} e_{d t}^{\lambda t i}
$$

$$
\begin{aligned}
-0,4688(0) & -0,4688 \\
\text { PI }(t) & =(2,71828)-(2,71828) \\
& =0,771
\end{aligned}
$$

$$
\begin{aligned}
& \mathrm{X}^{2}=\sum(f i-e l)^{2} / e l \\
& =14,9808<15.507 \text { (tabel) }
\end{aligned}
$$

Dari hasil perhitungan ini diketahui bahwa harga perhitungan lebih kecil dari harga tabel sehingga asumsi distribusi waktu antara dua kedatangan yang ditunjukkan dari gambar 4 adalah sesuai.

\section{Analisa Pola Waktu Pelayanan Terhadap Nasabah}

Frekuensi teoritis dihitung dengan rumus :

$$
\mathrm{e} 1=\mathrm{Pi} * \mathrm{n}=0.771 * 296=228,316
$$

Kemudian dianalisa dengan Kai Kuadrat dengan cara :

Derajad kebebasan dicari :

$$
\begin{aligned}
& \mathrm{v}=\mathrm{k}-\mathrm{g}-1 \\
& \mathrm{k}=10 \text { (kelas interval) } \\
& \mathrm{g}=\text { parameter }(\lambda)=1 \\
& \mathrm{v}=10-1-1=8
\end{aligned}
$$

Analisa pola waktu pelayanan sama dengan yang dilakukan terhadap analisa waktu 2 kedatangan nasabah diatas.

Namun hasil test statistik kesesuaian pola distribusi waktu pelayanan terhadap nasabah tidak diperoleh hasil yang sesuai berdasarkan teori yang ada, sehingga terjadilah penyimpangan dari asumsi yang biasa dipakai.

Dari perhitungań rata-rata populasi waktu Dengan tingkat signifikan $=5 \%$ diperoleh harga tabel

$$
X^{2}=15,507
$$
pelayanan nasabah diatas selanjutnya dapat dihitung kecepatan pelayan per satuan waktu $(\mu)$.

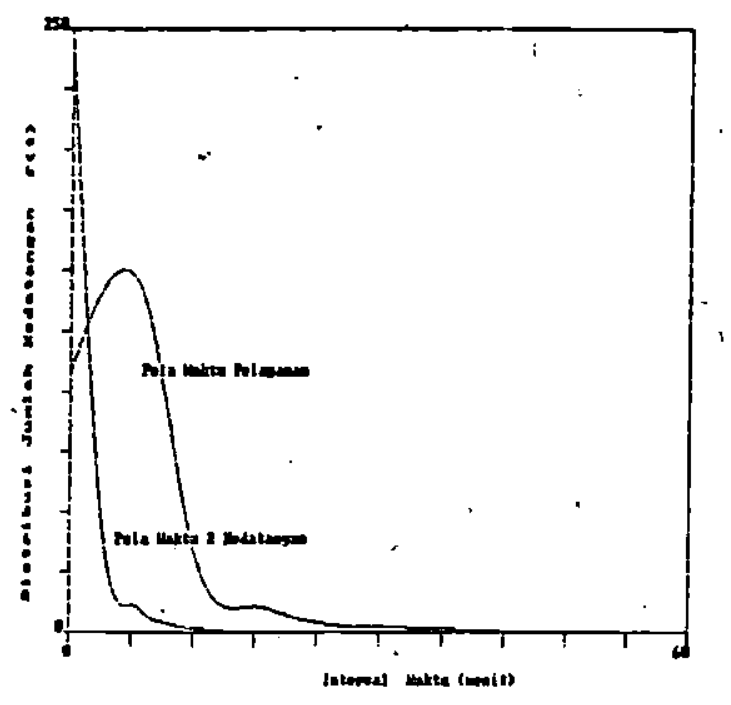

Gambar 5. Pola Waktu Kedatangan dan Pelayanan 
TABEL 3

DISTRIBUSI FREKUENSI, PROBABILITAS WAKTU PELAYANAN

\begin{tabular}{|c|c|c|c|c|}
\hline$t i$ & $\$ 1$ & $F^{\prime} j$ & $E i$ & $x^{2}$ \\
\hline $\begin{array}{r}1,02 \\
4,69 \\
8,397 \\
10,350 \\
15,150 \\
0 \\
0 \\
0 \\
0 \\
30,25\end{array}$ & $\begin{array}{r}243 \\
38 \\
10 \\
3 \\
1 \\
0 \\
0 \\
0 \\
1\end{array}$ & $\begin{array}{l}0,771 \\
0,174 \\
0,040 \\
0,0093 \\
0,00213 \\
0,00199 \\
F 7 \\
\quad F 8 \\
0.000269\end{array}$ & 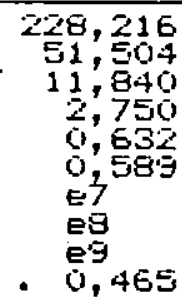 & $\begin{array}{c}0,5577 \\
3,5400 \\
0,2859 \\
1,1136 \\
0,5335 \\
0,5890 \\
= \\
0, \overline{5}\end{array}$ \\
\hline & 296 & 631,486 & . & 7,7320 \\
\hline
\end{tabular}

\section{TABEL 4}

\begin{tabular}{|c|c|c|c|}
\hline Intervel & $\mathrm{ii}$ & $t i$ & fiti \\
\hline 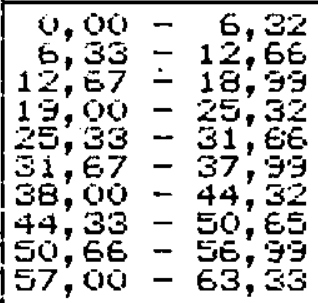 & $\begin{array}{r}109 \\
145 \\
24 \\
10 \\
3 \\
2 \\
1 \\
0 \\
0 \\
1\end{array}$ & 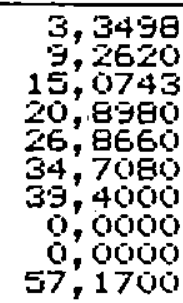 & $\begin{array}{r}365,1282 \\
1352,2520 \\
561,7832 \\
208 ; 9800 \\
90,5980 \\
69,4160 \\
39,4000 \\
0,0000 \\
0,0000 \\
57,1200\end{array}$ \\
\hline & 296 & 631,486 & 2534,6774 \\
\hline
\end{tabular}

TABEL 5

\begin{tabular}{|c|c|c|}
\hline Intervai & $\mathrm{Fi}_{i}$ & $t i$ \\
\hline 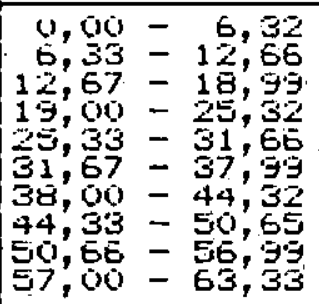 & $\begin{array}{l}9,528 \\
0,248 \\
0,119 \\
0,057 \\
0,027 \\
0,010 \\
0,0033 \\
0,00296 \\
0,00141 \\
0,00067\end{array}$ & $\begin{array}{r}3,3490 \\
9,2620 \\
15,0749 \\
20,8900 \\
34,7060 \\
39,4000 \\
0,0000 \\
5,0000 \\
5,1700\end{array}$ \\
\hline . & & 631,486 \\
\hline
\end{tabular}


Harga rata-rata populasi, $t$ :

$$
\begin{aligned}
& t=\frac{\sum f i . t i}{\sum f i}=8,563 \text { menit } \\
& \mu=\frac{1}{t}=0.1167
\end{aligned}
$$

D. Penyimpangan Pola Waktu Pelayanan

Telah disebutkan diatas bahwa ada penyimpangan terhadap pengujian pola waktu pelayanan, walaupun gambar grafik yang diperoleh menampakkan distribusi Eksponensial atau Erlang sehingga analisa selanjutnya dengan menggunakan rumusrumus -yang telah tersedia tak dapat dilakukan. Menurut Chase and Aquilano, Buffa kondisi ini dapat diselesaikan cukup dengan estimasi gambar grafik yang diperoleh (Gambar 5). Hal ini terjadi karena jumlah pelayanan lebih däri satu sehingga penyelesaian selanjutnya disarankan untuk menggunakan metode simulasi.

E. Persiapan Nilai-nilai Untuk Analisis Sistem Antrian

Persiapan nilai-nilai untuk analisa sistem adalah:

1. Rata-rata waktu kedatangan nasabah, $\mathrm{t}=2,133 \mathrm{menit} / \mathrm{nasabah}$.

2. Tingkat kedatangan rata-rata,

$$
\lambda=0,4688 \text { nasabah/mènit. }
$$

3. Distribusi bentuk kedatangan nasabah adalah Eksponensial.

4. Jumlah dari fasilitas pelayanan, $S=1,2$ dan $S=3$

5. Rata-rata waktu pelayanan. $t=8,563$ menit/nasabah.

6. Tingkat pelayanan rata-rata, $\mu=0,1167$ nasabah/menit.

7. Sumber Antrian Tak terbatas.

Dengan didasarkan input diatas, maka proses analisis sistem antrian dapat dijalankan.

\section{Hasil Studi}

Seperti telah disampaikan sebelumnya dikarenakan data yang diperoleh untuk distribusi pelayanan antrian secara perhitungan tidak diperoleh kesesuaian dengan hipotesa yang diasumsikan walaupun seçara grafis sangat meyakinkan bahwa distribusinya mengikuti distribusi Eksponensial atau Erlang maka untukmenganalisa sistem antrian dilakukan cara simulasi. Untuk mempercepat dan mempermudah perhitungan simulasi digunakan paket software QS tentang Queuing Simulation.
a. Input untuk Simulasi
1. Variabel-variabel yang akan disimulasi adalah :
a. Kurun waktu antar kedatangan, (T).
b. Kurun waktu pelayanan, (Lp).

2. Satuan yang akan disimulasi adalah dalam menit.

3. Jumlah fasilitas pelayanan, $S=1,2,3$.

4. Rata-rata waktu pelayanan dari perhitungan terdahulu didapat $t=8,563$ menit/nasabah, untuk $S=2$ dan $S=3$ diambil harga rata-ratanya yaitu $S=2=$ 4,2815 , dan $S 3=2,854$.

5. Distribusi bentuk pelayanan sesuai dengan gambar grafik yang diperoleh dibuat estimasi bentuk distribusi eksponensial dan Erlạng sebagai perbandingan.

6. Jumlah baris antrian (Queing) adalah 1.

7. Disiplin pelayanan FIFO.

8. Rata-rata waktu antar kedatangan dari perhitungan $t=2,135 \mathrm{meni} / \mathrm{nasabah}$.

9. Distribusi bentuk kedatangan adalah Eksponensial.

10. Priod waktu yang akan disimulasi yaitu dari jam 8.00 sampai dengan jam 12.00 W.I.B. 
b. Analisis jumlah loket optimal untuk distribusi pelayanan Eksponensial

\begin{tabular}{|c|c|c|c|}
\hline Juml an Lotiet & $\begin{array}{c}\text { Waktu tunggu } \\
\text { dalam sistem } \\
\text { (menit) }\end{array}$ & Utilitas. & $\begin{array}{l}\text { Tatal Frasen } \\
\text { tase mengang } \\
\text { gur }\end{array}$ \\
\hline$\frac{1}{2}$ & $\begin{array}{l}67,68 \\
20,88 \\
2,522\end{array}$ & 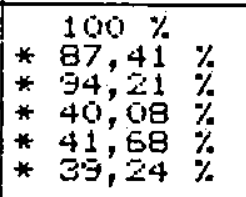 & $\begin{array}{c}0 \% \\
4,2 \% \\
54,1 \%\end{array}$ \\
\hline
\end{tabular}

c. Analisis jumlah loket optimal untuk distribusi pelayanan Erlang.

\begin{tabular}{|c|c|c|c|}
\hline Jumlah Loket & $\begin{array}{l}\text { waktu tunggu } \\
\text { dalam sistem } \\
\text { ('menit) }\end{array}$ & $\begin{array}{c}\text { Utilitas } \\
. \rho\end{array}$ & $\begin{array}{l}\text { Tatal Frasen } \\
\text { tase mengang } \\
\text { gur. }\end{array}$ \\
\hline $\begin{array}{l}1 \\
2 \\
3\end{array}$ & $\begin{array}{l}43,13 \\
12,53 \\
2,522\end{array}$ & $\begin{array}{l}100 \% \\
* \quad 94,80 \% \\
* \quad 96,34 \% \\
* 40,08 \% \\
* \quad 31,68 \% \\
* 39 \%\end{array}$ & $\begin{array}{l}4,43 \% \\
57 \%\end{array}$ \\
\hline
\end{tabular}

Jika diasumsikan Pimpinan Bank \% dari waktu keseluruhan kerja maka hasil memerintahkan bahwa pelayanan terhadap Simulasi dapat dibandingkan sebagai nasabah maksimal 15 menit dan waktu berikut: menganggur pelayanan tidak lebih dari 15

TABEL 5

Perbandingan $E\left(T_{\imath}\right)$ Dan $P_{0}$ Hasil Simulasi Untuk $S=1,2$ Dan $S=3$ Dengan ketetapan Pimpinan

Pâda Distribusi Pelayanan Eksponensial

\begin{tabular}{|c|c|c|c|c|}
\hline Server & $E\left(T_{t}\right)=w$ & $F_{g}$ & $\theta$ & $\theta$ \\
\hline$\frac{1}{2}$ & 67,68 menit & $0,00 \%$ & 15 menit & $15 \%$ \\
3 & 29,88 Menit & $4,20 \%$ & 15 menit & $15 \%$ \\
\hline
\end{tabular}

TABEL 6

Perbandingan $E$ (Tt) Dan Po Hasil Simulasi Untuk $S=1,2$ Dan $S=3$

Dengan Ketetapan Pimpinan Pada Distribusi Pelayanan Erlang

\begin{tabular}{|c|c|c|c|c|}
\hline Server & $E\left(T_{t}\right)=w$ & $F_{a}$ & $\theta$ & $\theta$ \\
\hline$\frac{1}{3}$ & 83,19 men'it & $0,00 \%$ & 15 menit & $15 \%$ \\
& 12,5 menit & $4,43 \%$ & 15 menit & $15 \%$ \\
\hline
\end{tabular}


Berdasarkan tabel 5 dan 6 diatas kita dapat melihat bahwa walaupun telah diadakan simulasi terhadap sistem antrian, namun untuk memenuhi kriteria yang ditetapkan oleh pihak pimpinan adalah sangat sulit. Namun demikian haru's diambil suatu keputusan sebagai usulan untuk mencari penyelesaian yang optimal terhadap pelayanan nasabah yang datang.

Untuk tahap pertama diperbandingkan terlebih dahulu perbedaan distribusi pelayanan eksponensial dan Erlang untuk mencari distribusi pelayanan yang sesuai. Dari tabel 5 dan 6 diperoleh kesimpulan bahwa distribusi pelayanan Erlang terhadap nasabah lebih baik hasilnya dibandingkan distribusi Eksponensial. Dari tabel 5, ternyata pemakaian 2 server/counter/ pelayan adalah yang terbaik dibandingkan dengan pemakaian 1,3, dst server karena waktu tunggu seorang nasabah dalem antrian tidak terlalu lama yaitu 12,59 menit dan walaupun waktu menganggur para pelayan sebesar $4,43 \%$ dari selunuh waktu yang digunakan $(4,43 \% \times 2 \times 240$ menit $=$ 21,26 menit).

\section{Kesimpulan}

Studi diatas menghasilkan kesimpulan sebagai berikut :

- Untuk jumlah loket (server), $S=1$ diperoleh :

1. Rata-rata waktu yang dialami seorang nasabah di dalam sistem adalah 83,19 menit.

2. Rata-rata waktu menganggur dari fasilitas pelayanan adalah $0,00 \%$.

3. Tingkat kegunaan dari fasilitas pelayanan adalah $100 \%$.

- Untuk jumlah loket (server), $S=2$ diperoleh :

1. Rata-rata waktu yang dialami seorang nasabah di dalam sistem adalah 12.59 menit.

2. Rata-rata waktu menganggur dari fasilitas pelayanan adalah $4,43 \%$.

3. Tingkat kegunaan dari fasilitas pelayanan adalah $95,57 \%$.

- Untuk jumlah loket (server), $S=3$ diperoleh :

1. Rata-rata waktu.yang dialami seorang nasabah di dalam sistem adalah 2,99 menit.

2. Rata-rata waktu menganggur dari fasilitas pelayanan adalah $56,92 \%$.

3. Tingkat kegunaan dari fasilitas pelayanan adalah $129,236 \%$.

Dari hasil simulasi tersebut di tempat pelayanan yang optimal pada periodeperiode sibuk adalah 2 buah loket Transfer.

\section{Saran-saran}

1. Dari hasil studi ini nampak adanya penyimpangan terhadap pola distribusi yang biasa diasumsikan dari teori yang ada sehingga sangat dimungkinkan untuk diteliti lebih lanjut, sehingga dengan demikian akan menambah hasanah pengembangan teori antrian.

2. Dari hasil perhitungan simulasi disarankan pula disaat periode-periode sibuk hendaknya jumlah loket transfer yang disediakan 2 buah, agar waktu tunggu bagi nasabah di dalam sistem tidak terlalu lama,sehingga garis antrian tidak panjang, walaupun pengaruh waktu menganggur selama 4 jam kerja efektif (240 menit waktu simulasi) adalah sebesar $4,43 \%(21,26$ menit). Waktu menganggur yang tersedia ini barangkali dapat dialokasikan pada pekerjaan tambahan yang lain. 


\section{Daftar Pustaka}

- Anderson D, Sweeney J.D, William A.T., 1988. Management Sciensce, Quantitative Approach to Decision Making, Fifth Edition, West Publishing and co, Minnesota, USA.

- Buffa, Elwood S., 1980. Modern Production/Operation Eighth Edition, John Wiley \& Sonc, Inc, New York.

- Chairul Saleh, 1993. Sistem Kuantitatif Untuk Bisnis, Buku I, Cetakan Pertama, Penerbit Dana Bhakti Wakaf, Yógyakarta.

- Chase And Aquilano, 1985. Production and Operation Management A Life Cycle Approach Forth Edition Irwin Homewood, Illinois, USA.

- Gelders L., 1981. Quantitative Methode Xn Management, Katholieke Universiteit Te Leuven.
- Jay Heize, Barry Render, 1988. Production and Operation Management "Strategy and Tactics" Allyn aand Bacon, Inc, USA.

- Lee, Moore, Taylor, 1990. Management Science, Third Edition, Allyn and Bacon, USA.

- Levin, Richard I, Rubin, Davids, Stinson, Joel P. 1986. Quantitative Approaches To Management, (sixthEdition), Mc Graw - Hill International Edition.

- Markam, Robert E., \& Sweigart, James R., 1987. Quantitative Methode : Application To Managerial Decision Making.

- Taha, Hamdy A., 1982, Operation Research (Third Edition), Mc Millan Publishing Co., Inc., New York.

- Winston L. Wayne, 1988. Operation Research : Aplication and Algorithms. PWS-KENT Publishing Company, USA. 